\title{
THE EXISTENCE OF MEDIA EDUCATION IN IMPROVING THE QUALITY OF HUMAN RESOURCES
}

\author{
${ }^{1}$ Dr. Ahdar, M.Pd.I., ${ }^{2}$ Dr. Musyarif, M.Ag \\ Dosen IAIN Parepare ${ }^{1,2}$
}

\begin{abstract}
In this regard, which can be advanced is are people who have qualified human resources. Demands and urging mankind to be independent and do not depend on institutions that can recruit later after plunging into the world of work. Because given the employment is getting narrower and more and more unemployment. Therefore, in answering this question in the competent institutions must cultivate human resources. In the world of education has several important elements, one of which is the media. Media merupakan alat komunikasi dan informasi yang dapat mengakses ilmu pengetahuan kepada anak didik. Whether a successful learning process in the world of education is strongly influenced by the role of the media.
\end{abstract}

Keywords: Media education, the quality of human resources

Abstrak: fenomena kontemporer mendeskripsikan persaingan hidup yang konpetitif. Dalam hal ini, yang dapat menjadi maju ialah ialah orang-orang yang memiliki sumber daya manusia yang handal. Tuntutan dan desakan umat manusia agar dapat mandiri dan tidak tergantung kepada lembaga-lembaga yang dapat merekrut nantinya setelah terjun ke dunia kerja. Sebab mengingat lapangan kerja semakin sempit dan semakin membludaknya pengangguran. Oleh karena itu, dalam menjawab persoalan ini lembaga pendidikanlah yang berkompeten dalam membina manusia memiliki sumber daya. Dalam dunia pendidikan memiliki beberapa elemen penting, salah satu di antaranya adalah media. Media merupakan alat komunikasi dan informasi yang dapat mengakses ilmu pengetahuan kepada anak didik. Berhasil tidaknya proses belajar dalam dunia pendidikan sangat dipengaruhi oleh peran media.

Kata kunci: Media Pendidikan, Kualitas SDM

\section{Pendahuluan}

Media merupakan alat informasi dan komunikasi, yang dapat mengakses data secara efektif dan efisien karena menggunakan alat bantu. Alat Bantu yang memediasi atau sebagai 'jembatan' dalam penyampaian pesan dari sumber (subyek) kepada sasaran (obyek). Adanya proses interaksi antara subyek dan obyek terimplikasi untuk saling take and give. Proses tersebut yakni saling mengisi (brainstorming) sehingga terjadi feedback yang mengarah kepada proses transformasi. Orientasi dan sasaran media berkaitan erat dalam aktivitas dunia pendidikan.

Pendidikan secara esensial adalah aktualisasi belajar mengajar. Kegiatan belajar dan mengajar bagai dua keping mata uang yang sangat erat kaitanya dan tidak bisa dipisahkan. Kalau ada proses belajar maka pasti ada proses mengajar, begitu juga sebaliknya, jika terjadi aktivitas 
mengajar maka tentu terjadi proses belajar juga. Namun. Proses belajar dapat terjadi kapan dan dimana saja serta tidak terlepas dari ada yang mengajar walau dalam keadaan tersirat. Proses belajar terjadi karena adanya interaksi individu dengan lingkungannya. Hal ini dapat dilihat, salah satu indikasi seseorang belajar sesuatu adalah adanya perubahan tingkah laku dalam dirinya (Arief S. Sadiman dkk, 1996). Perubahan tingkah laku tersebut menyangkut baik perubahan yang bersifat pengetahuan (kognitif), ketrampilan (psikomotorik), maupun yang menyangkut nilai atau sikap (efektif).

\section{Metode}

Lingkungan belajar yang diatur oleh pengajar mencakup tujuan pengajaran, bahan pengajaran, metode pengajaran dan penilaian pengajaran. Unsure-unsur tersebut dapat dikenal dalam komponenkomponen pendidikan. Dalam interaksi belajar mengajar, salah satu unsure yang paling berperan adalah aspek metodologi pengajaran. Dalam metodologi pengajaran, ada dua segmen yang paling menonjol yaitu metode mengajar dan media pengajaran sebagai alat bantu pengajaran (Nana Sudjana, 1997). Dengan demikian, menjadi bagian yang urgen dalam mengimplementasikan kegiatan pendidikan.

Media pengajaran dapat meningkatkan kegiatan proses belajar anak didik, yang pada gilirannya diharapkan dapat mempertinggi hasil belajar yang dicapainya. Media pengajaran dapat mempertinggi proses belajar mengajar anak didik dengan alasan sebagai berikut:

Berkenaan dengan manfaat media pendidikan dalam proses belajar mengajar: lebih menarik sehingga dapat membangkitkan motivasi, baha pengajaran akan lebih jelas maknanya sehingga mudah dipahami, metode pengajaran bervariasi sehingga anak didik tidak bosan dan guru tidak terkuras tenaga, anak didik lebih banyak melakukan kegiatan belajar. Yang berkenaan dengan taraf berpikir siswa, yang mengikuti tahap perkembangan dimulai dari berpikir kongkrit menuju berpikir abstrak, dimulai berpikir sederhana sampai berpikir kompleks (Nana Sudjana, 1997).

Uraian tersebut di atas, memberikan gambaran bahwa media pengajaran berorientasi pada peningkatan kualitas belajar mengajar. 
Kualitas belajar mengajar menstransmisikan out-put pendidikan yang berkualitas.

\section{Hasil}

Media pengajaran berimplementasi dalam proses belajar mengajar. Media pengajaran cukup berperan dalam mengelola kegiatan dalam mencapai tujuan pengajaran. Adapun tujuan pengajaran ialah adanya transformatif individu, masyarakat dan professional (Hasan Langgulung, 1979). Tujuan tersebut berupa pengembangan individu, peningkatan masyarakat (bagian dari individu) dan perbaikan motif kerja secara professional. Olehnya itu, media pengajaran berelasi langsung pada pengembangan potensi anak didik agar dapat menjadi anak didik yang akseptabel baik secara kognitif, afektif maupun secara psikomotorik.

Kualitas belajar mengajar yang baik akan membentuk kepribadian anak didik yang paripurna. Bila kreativitas belajar mengajar rendah maka akan berkonsekuensi langsung pada kualitas out-put pendidikan yang rendah. Secara empiris bahwa proses yang tidak relevan atau kurang fair maka out-put akan kurang fair pula, dan apabila dalam proses belajar mengajar sesuai dengan mekanisme dan prosedur kerja, maka akan menghasilkan luaran optimal yang sesuai dengan sasaran yang diinginkan. Jadi kualitas belajar mengajar 'menyublimasi' anak didik yang berkualitas. Anak didik yang berkualitas otomatis mampu berperan aktif dalam mengisi setiap kekosongan pangsa pasar dan bersifat fungsional di dalam masyarakat. Apabila anak didik siap pakai di bidang spesialisasinya berarti telah memiliki sumber daya manusia yang handal.

Oleh karena itu, sumber daya manusia secara umum adalah produk dari pendidikan. Substansi pendidikan membentuk kepribadian anak yang memiliki sumber daya manusia yang handal. Namun, tidak semua out-put pendidikan melahirkan generasi yang memiliki sumber daya manusia yang unggul. Problem ini punya keterkaitan dengan komponen-komponen pendidikan - sampai sejauh mana setiap komponen pendidikan mempunyai sinkronisasi dan relevansi dalam menjalankan kegiatan belajar mengajar terutama pada penggunaan, pengelolaan, pemilihan media pengajaran yang tepat guna.

Dari diskursus di atas, dapat dianalisis bahwa proses dan hasil belajar para anak didik menunjukkan perbedaan yang signifikan antara pengajaran tanpa media dan pengajaran dengan media (Arief S. Sadiman 
dkk, 1996). Oleh sebab itu, penggunaan media pengajaran dalam proses belajar mengajar sangat dianjurkan bahkan dituntut untuk meningkatkan kualitas dan mutu pengajaran. Jadi dengan penggunaan media pengajaran dilakukan secara efektif maka meretaskan hasil yang maksimal pada anak didik dalam mengembangkan potensinya. Dari sisi ini, dapat ditarik 'benang merahnya' bahwa antara media pengajaran (pendidikan) dan sumber daya manusia memiliki hubungan yang erat. Karena media pendidikan merupakan alat atau sarana dalam melakukan aktivitas pendidikan yang efektif dan efisien yang menjadi 'embrio' bagi pembentukan sumber daya manusia yang berkualitas.

\section{Pembahasan}

Media merupakan sarana yang sangat penting dalam pelaksanaan pengajaran dan pendidikan. Media menjadi elemen atau komponen pendidikan yang harus diperhatikan dalam meningkatkan efektifitas pembelajaran. Karena dengan media dalam pendidikan akan membantu proses belajar mengajar yang baik sehingga dapat tercapai tujuan pendidikan yang diharapkan.

Dalam hal ini, Sudarwan Danim dalam bukunya dengan judul Media komunikasi Pendidikan berpendapat bahwa :

Media pendidikan meruapakan seperangkat alat Bantu atau pelengkap yang digunakan oleh guru atau pendidik dalam rangka berkomunikasi dengan anak didik. Alat Bantu itu disebut media pendidikan, sedangkan komunikasi adalah system penyampaiannya (Sudarwan Danim, 1994).

Media pendidikan itu banyak dan bervariasi sehingga dangat diperlukan ilmu manajemen dalam mengelolanya. Dalam pengelolaan dan pemanfaatan media pendidikan menuntut kajian tersendiri, sesuai dengan kebutuhan dan tuntutan anak didik, materi yang disajikan, media yang digunakan, prosedur dan organisasi - harus merupakan bagian integral di bawah kontrol khusus para pendidik atau penyelenggara pendidikan.

Media pendidikan sebagai bagian integral dari kegiatan pendidikan, memerlukan upaya manusia (guru dan tenaga kependidikan/ sekelompok professional lainnya) yang bersifat menyeluruh. Karena media hanya merupakan bagian dari upaya memanfaatkannya dan mengkaji kegiatan belajar mengajar berdasarkan pendekatan infrastruktur, memerlukan ketrampilan tersendiri. Upaya pendidikan diarahkan untuk mencapai tujuan pendidikan yang bermutu secara kualitatif, ini bukanlah aktivitas yang 
sederhana. Salah satu upaya yang mungkin dapat dilakukan adalah dengan jalan memanfaatkan media pendidikan dalam rangka efektivitas dan efisiensi manajemen pendidikan.

Dalam pemanfaatan media pendidikan, guru harus melakukan pemilihan yang tepat, karena pemilihan media harus menunjang pencapaian tujuan intruksional. Dalam pemilihan media diperlukan pertimbangan-pertimbangan seperti seberapa jauh dan lata pekerjaan yang sebenarnya perlu ditiru dalam program latihan, media apa yang paling praktis, apakah media yang akan digunakan itu relevan dengan materi pelajaran, apakah media sesuai dengan kapasitas, situasi dan kondisi anak didik, sejauhmana pencapaian anak didik harus sesuai dengan sasaran yang ditentukan, apakah nilai bahan pelajaran sepadan dengan harga media dan sebagainya. Dalam proses pemilihan media pendidikan yang efektif dan efisien, isi dan tujuan intruksional haruslah sesuai dengan karakteristik media tertentu (Hadi dkk, 1987).

Pemilihan media pendidikan untuk kepentingan pengajaran, sebaiknya memperhatikan criteria-kriteria di bawah ini, yakni sebagai berikut

a. Ketepatannya dengan tujuan pengajaran.

b. Dukungan terhadap isi bahan pengajaran.

c. Kemudahan memperoleh media

d. Keterampilan guru dalam mengaplikasikan.

e. Tersedia waktu dalam mengekspresikan.

f. Sesuai dengan taraf berpikir siswa (Nana Sudjana dan Ahmad Riva'l, 1997)

Dengan kriteria tersebut, akan mempermudah pelaksanaan kegiatan belajar mengajar, sehingga dalam pencapaian tujuan intruksional yang berarti.

Dari segi teori belajar, berbagai kondisi dan prinsip-prinsip psikologis yang perlu mendapat pertimbangan pemilihan dan penggunaan media adalah sebagai motivasi, perbedaan individual, tujuan pembelajaran, organisasi, isi, persiapan sebelum belajar, emosi, partisipasi, umpan balik, penguatan (reinforcement) latihan dan pengulangan, penerapan (Azhar Arsyad, 2002).

Telaah di atas mengemukakan bahwa media digunakan apabila mendukung tercapainya tujuan intruksional yang telah dirumuskan yang 
sesuai dengan sifat materi intruksionalnya. Oleh karena itu, media seharusnya digunakan dengan perencanaan yang sistematik. Supaya media dapat digunakan secara efektif dan efisien, ada tiga langkah utama yang perlu diikuti dalam penggunaan media, yaitu "persiapan sebelum menggunakan media, kegiatan selama menggunakan media, kegiatan tindak lanjut" (Arief S. Sadiman dkk, 1996).

Pemanfaatan media dapat berjalan dengan baik apabila disusun perencanaan dan persiapan yang baik pula. Dengan mempelajari literature yang telah disediakan, kemudian mengikut petunjuk-petunjuk teknis dan pelaksanaan yang berhubungan dengan tujuan-tujuan yang akan dicapai. Peralatan yang diperlukan juga disiapkan sebelumnya, agar tidak menganggu dengan hal-hal yang mengurangi kelancaran penggunaan media. Peralatan media perlu ditempatkan dengan baik agar audience dapat memperhatikan dan menyimak dengan baik pula. Jika media digunakan secara berkelompok sebaiknya tujuan dibicarakan agar tercapai persamaan persepsi. Hal ini penting supaya perhatian dan pikiran terarah ke titik sentral yang sama.

Begitu pula dalam menggunakan media, yang perlu dijaga adalah suasana ketenangan agar terhindar dari hal-hal yang dapat menganggu perhatian dan konsentrasi. Ruangan jangan terlalu gelap supaya dapat menulis hal-hal yang penting atau menulis pertanyaan bila ada yang belum dipahami. Bila menulis atau menggambar atau resume, hindari hal-hal yang dapat mengalihkan perhatian dan sajian media yang sedang berjalan. Ketika media digunakan untuk berkelompok, maka perlu menjaga ketenangan dan tidak berbicara yang bias menganggu teman yang lain dan bila ada perintah seperti menunjuk gambar, membuat garis, menyusun sesuatu dan lain-lain, sebaiknya dijalankan dengan tenang, jangan sampai menganggu teman yang lain.

Kegiatan follow up yaitu untuk menjaga apakah tujuan telah dicapai dan untuk menetapkan pemahaman terhadap materi intruksional yang disampaikan melalui media yang bersangkutan. Untuk itu, soal tes yang disediakan perlu kita kerjakan dengan segera sebelum kita lupa isi program media itu, kemudian kita cocokkan jawaban kita dengan kunci jawaban yang disediakan. Bila masih ada kesalahan sebaiknya mengulangi sajian program media yang bersangkutan. Jika belajar secara berkelompok perlu mengadakan diskusi kelompok untuk membahas jawaban soal tes atau hal- 
hal yang belum dipahami, kemudian ada saat tertentu yang memungkinkan melakukan tindak lanjut, misalnya dengan melakukan percobaan, melakukan observasi, menyusun sesuatu dan sebagainya.

Dari pemaparan strategi pemanfaatan media pendidikan, memberikan deskripsi bahwa dalam strategi pemanfaatan media pendidikan dilakukan sesuai dengan kebutuhan dan tututan, maka dengan pencapaian tujuan pendidikan dapat berjalan secara efektif dan efisien. Kemudian telah diuraikan sebelumnya bahwa dalam penggunaan media dibutuhkan skill, karena dengan skill yang professional, media dapat berfungsi dan berperan dengan baik. Semakin tinggi sikap professional seseorang dalam mengelola media semakin tinggi pula sikap kreativitas dalam suasana pendidikan yang dinamis. Apabila dalam pendidikan terjadi dinamika, maka sasaran utamanya adalah pembentukan kepribadian yang utama yakni memiliki sumber daya manusia yang unggul.

Dengan demikian, antara strategi pemanfaatan media pendidikan dan peningkatan sumber daya manusia merupakan garis siklus yang masing-masing memberikan konstribusi dan menjadi garis kontiniunitas yang tidak terputus sebagaimana gambar table berikut ini:

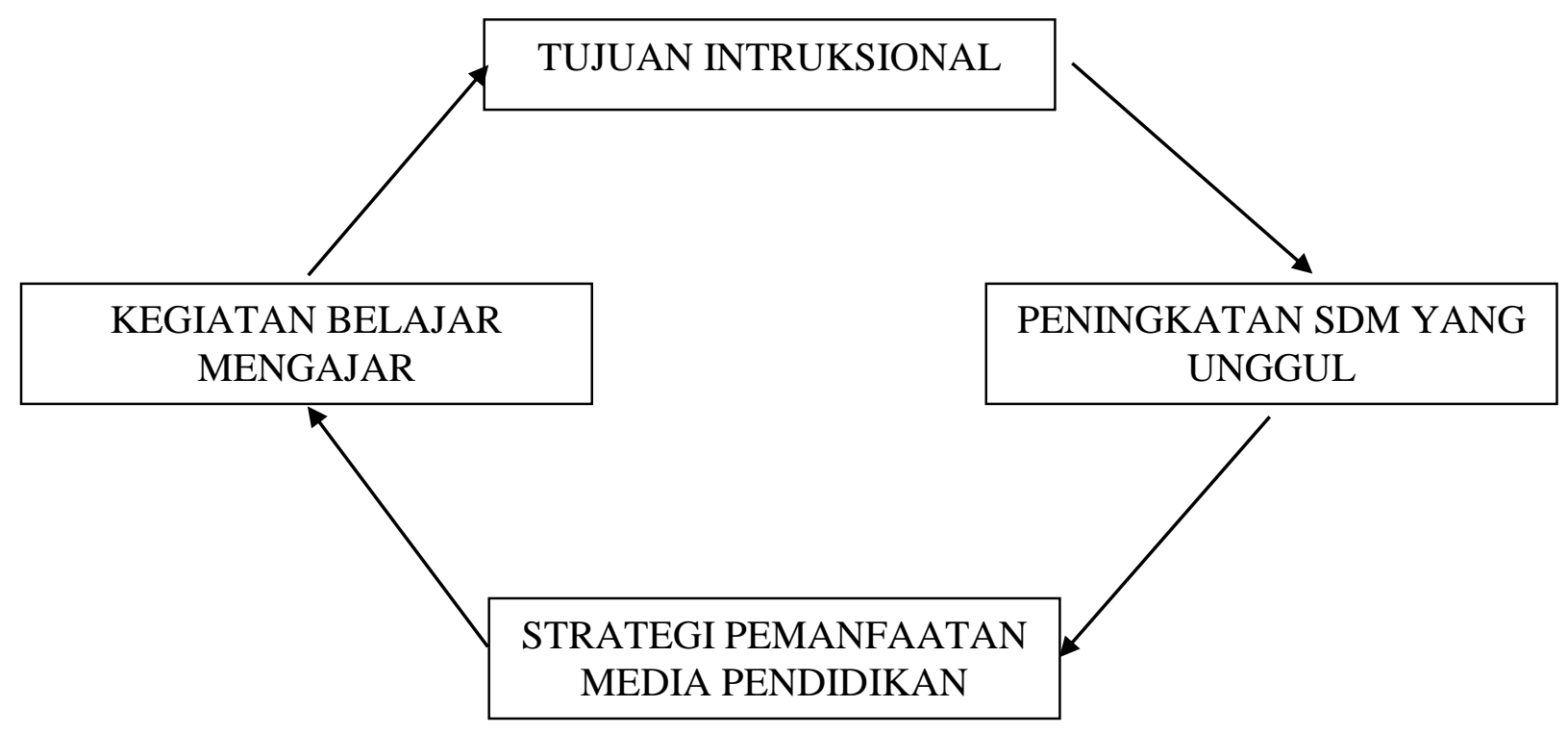


Jadi dalam strategi pemanfaatan media dapat dianalisis dalam membuat simpulan sebagai berikut :

a. Strategi pemanfaatan media pendidikan harus sesuai taraf berfikir anak didik.

b. Strategi pemanfaatan media pendidikan relevan dengan iklim kontemporer dan berorientasi ke depan.

c. Strategi media pendidikan sebagai wahana peningkatan moralitas dan penggunaan teknologi modern sebagai wahana aplikatif ketika terjun ke masyarakat.

d. Memperhatikan bakat dan minat anak didik dan berorientasi profesionalisme.

e. Strategi tersebut harus menciptakan suasana ketenangan, suasana keakraban dan sebagainya.

Peningkatan kualitas sumber daya manusia melalui lembaga pendidikan, sangat dipengaruhi oleh peran serta media pendidikan. Karena itu, eksistensi dan fungsi media dalam pendidikan dan pengajaran senantiasa diarahkan pada peningkatan kualitas sumber daya manusia. Apalagi dalam dunia pendidikan dituntut untuk melahirkan generasi yang berkualitas; beride berilyan, berakhlak mulia dan professional di bidangnya. Olehnya itu, pengadaan media pendidikan hendaknya yang mendukung peningkatan sumber daya manusia.

Media merupakan alat yang efektif dalam memberikan manfaat yang semaksimal mungkin kepada masyarakat sesuai dengan ketepatan dan besarnya pengarahan. Media tersebut dapat memainkan peranan penting dalam membina generasi dan mendorongnya untuk mengembangkan 'telaten' demi kemajuan baginya. Dan salah satu cara untuk memberantas buta wawasan pada sebagian kaum terpelajar hanya dengan bantuan media.

Secara universal, media merupakan transmisi perubahan dalam diri individu dan masyarakat. Club of Rome menerbitkan sebuah buku dengan judul The First Global Revolution, yang menjelaskan tentang prospek dan proyek media dalam sisi keehidupan umat manusia. Uaraian buku tersebut meramalkan bahwa media adalah salah satu dari ketiga kekuatan utama yang akan sangat mempengaruhi umat manusia di abad 21 (Alvin Saputra, t.th). Media ada di sekeliling kita, mendominasi kita dan bahkan mempengaruhi emosi serta pertimbangan kita. Marchall Meluhan 
mengemukakan dalam bukunya Understanding Media the Extensi of Man, menganggap bahwa media juga menciptakan serta mempengaruhi cakupan serta bentuk hubungan-hubungan dan kegiatan-kegiatan manusia (Alvin Saputra, t.th).

Seiring akselerasi ilmu pengetahuan dan teknologi, dunia semakin mengglobal dan mengarah kepada uniformitas. Sains telah meretaskan media begitu menjamur, sehingga media tersebut merambah ke seluruh segmen kehidupan. Ketika media banyak mampu menggeser pola kehidupan dari tersekat-sekat menjadi sejagad, dari primitif menjadi modernis, dari tradisional menjadi rasional dan sebagainya. Dobrakan transformatif dari bias media menuntut umat manusia untuk meningkatkan kehidupannya agar tetap eksis dan survival. Dampak tersebut membawa ke dalam iklim kompetitif yang ketat. Hal ini mendorong manusia untuk bersaing demi mempertahankan martabatnya. Bagi orang yang tidak sanggup bersaing akan tergilas oleh dinamika zaman. Olehnya itu, agar tetap eksis baik dalam kancah komunal maupun dalam tataran global, maka manusia senantiasa meningkatkan kualitasnya. Dengan demikian, korelasi peranan media dalam kehidupan, mendesak agar setiap umat manusia memiliki sumber daya yang berkualitas.

Melihat kebutuhan dan tuntutan sumber daya manusia di era global, tentu perhatian dan harapan kita tertuju kepada pendidikan. Sebab, pendidikan memiliki tanggung jawab yang besar dalam kerangka membangun, membina dan mengembangkan kualitas manusia yang dijalankan secara terstruktur, sistematis dan terprogram serta berkelanjutan (M. Dawam Rahardjo, 1997). Tuntutan dan dinamika hidup yang berkembang dalam masyarakat harus pula diiringi oleh dinamika pendidikan - bahkan pendidikan seharusnya mengarahkan dinamika masyarakat. Namun, era kontemporer lembaga pendidikan menghadapi tantangan yang besar terutama industrialisasi. Olehnya itu, pendidikan harus menghasilkan produk yang bermutu, terampil dan professional.

Kolaborasi antara media yang berbasis teknologi dan pendidikan sangat urgen, karena pendidikan yang memiliki media berbasis teknologi dapat menunjang pengajaran yang berkualitas seperti memperlancar proses belajar mengajar, memberikan dorongan untuk maju kepada anak didik, keaktifan, minat yang tinggi serta memudahkan menerima pelajaran dan menghayatinya. Senada dengan hal tersebut di atas, Yusuf Hadi 
Miarso dalam bukunya Teknologi Komunikasi Pendidikan, mengatakan bahwa "Media pendidikan secara umum mempunyai kegunaan untuk mengatasi hambatan dalam berkomunikasi, keterbatasan fisik dalam kelas, sikap positif peserta didik serta mempersatukan pengamatan anak didik" (Yusuf Hadi Miarso, 1984).

Menurut Donald P. Ely, bahwa media pendidikan mempunyai beberapa manfaat yaitu meningkatkan produktivitas pendidikan, memberi dasar yang lebih dinamis terhadap pendidikan, pengajaran yang lebih mantap, memungkinkan belajar seketika dan penyajian pendidikan lebih luas (Donald P. Ely, 1997). Kemudian lebih lanjut tentang manfaat media pendidikan secara detail, (Sudarwan Danim, 1994). menjelaskan sebagai berikut :

1. Meningkatkan mutu pendidikan dengan jalan mempercepat rate of learning, membantu guru menggunakan waktu belajar secara lebih baik, mengurangi beban guru dalam menyajikan informasi, aktivitas guru lebih banyak diarahkan untuk meningkatkan kegairahan anak.

2. Memberi kemungkinan pendidikan yang sifatnya lebih individual dengan jalan memperkecil atau mengurangi kontrol guru yang tradisional dan kaku, memberi kesempatan luas kepada anak didik untuk berkembang menurut kemampuannya, memungkinkan mereka belajar menurut cara yang dikehendaki.

3. Memberi dasar pengajaran yang lebih ilmiah dengan jalan menyajikan atau merencanakan program pengajaran secara logis dan sistematis, mengembangkan kegiatan pengajaran melalui penelitian, baik sebagai pelengkap maupun sebagai terapan.

4. Pengajaran dapat dilakukan secara mantap dikarenakan meningkatnya kemampuan manusia sejalan dengan pemanfaatan media komunikasi, informasi dan data dapat disajikan lebih kongkrit dan rasional.

5. Meningkatnya perwujudan immediancy of learning, karena media dapat menghilangkan atau mengurangi jurang pemisah antara kenyataan di luar kelas dengan kenyataan di dalam kelas, memberikan pengetahuan langsung.

6. Memberikan penyajian pendidikan lebih luas, terutama melalui media massa dengan jalan memanfaatkan secara bersama dan lebih luas 
peristiwa-peristiwa langkah, menyajikan informasi yang tidak terlalu menekankan batas ruang dan waktu.

\section{Kesimpulan}

Uraian di atas, memberikan ilustrasi-ilustrasi penting kepada kita bahwa media pendidikan dan pemanfaatannya untuk tujuan pendidikan mempunyai manfaat yang luas. Media pendidikan memungkinkan kegiatan belajar mengajar lebih produktif, ilmiah, diindividualisasikan, power full immediancy, sejalan dengan ilmu pengetahuan dan teknologi.

Berangkat dari wacana sentral di atas, penulis dapat memberikan simpulan bahwa peranan media pendidikan sebagai suatu kontributor penting dalam meningkatkan sumber daya manusia, yaitu sebagai berikut :

a. Media pendidikan sangat berpengaruh dalam menentukan berhasil tidaknya anak didik dalam belajar.

b. Media pendidikan banyak ragamnya, apabila dikelola secara professional akan menunjang pengembangan sumber daya manusia.

c. Media sebagai sarana penyalur informasi dan komunikasi yang mudah didapatkan, baik dalam kalangan keluarga maupun dalam lingkungan masyarakat, hal ini berarti dapat dipakai kapan saja dalam mengembangkan potensinya.

d. Media pendidikan yang berbasi teknologi akan menunjang dalam meningkatkan sumber daya manusia.

\section{Daftar Pustaka}

[1] Ahmad Riva'l, Nana Sudjana. Media Pengajaran, Cet, III, Bandung : Sinar Baru, 1997.

[2] Arsyad, Azhar. Media Pembelajaran, Cet. III, Jakarta : Raja Grafindo Persada, 2002.

[3] Danim, Sudarwan. Media Komunikasi Pendidikan, Jakarta : Bumi Aksara, 1994.

[4] Ely, Donald P. Intruktional Design and Develovment Participant's Note Book, Jakarta : TKPK Depdikbud, 1997.

[5] Langgulung, "Falsafah Pendidikan Islam, Jakarta : Bulan Bintang, 1979. 
[6] Miarso, Yusuf Hadi et.al., Teknologi Komunikasi Pendidikan - Pengertian dan Penerapannya di Indonesia, Cet. I, Jakarta : Rajawali, 1984.

[7] R.H. Anderson, Selection and Developing Media for Intruction, diterjemahkan oleh usuf Hadi dkk., "Pemilihan dan Pengembangan Media Untuk Pembelajaran, Jakarta : Rajawali, 1987.

[8] Rahardjo, M. Dawam (ed.), Keluar dari Kemelut Pendidikan Nasional Menjawab Tantangan Kualitas SDM Abad 21, Jakarta : Intermasa, 1997.

[9] Saddam, Samad Umarella M. Sahrawi Saimima. "MEDICAL URGENCE IN THE LEARNING PROCESS." al-Iltizam: Jurnal Pendidikan Agama Islam 3.2 (2018): 237-245.

[10] Sadiman, Arief S. (dkk). Media Pendidikan - Pengertian, Pengembangan dan Pemanfatannya, Jakarta: Rajawali Press, 1996.

[11] Seyling Wen, Future of the Media, diterjemahkan oleh Alvin Saputra, Masa Depan Media - Memahami Zaman Teknologi Informasi, ( Batam : Lucky ublishers, t.th).

[12] Saddam, Samad Umarella M. Sahrawi Saimima. "MEDICAL URGENCE IN THE LEARNING PROCESS." al-Iltizam: Jurnal Pendidikan Agama Islam 3.2 (2018): 237-245.

[13] Sudjana, Nana Media Pengajaran, Media Pendidikan, Cet. III, Bandung : Sinar Baru, 1997. 